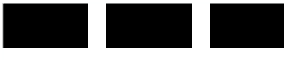 \\ m \\ THE WiLliam DAVIDSON INSTITUTE AT THE UNIVERSITY OF MICHIGAN BUSINESS SCHOOL
}

\section{Trade Creation and Diversion Effects of Europe's Regional Liberalization Agreements}

\author{
By: Yener Kandogan
}

William Davidson Institute Working Paper Number 746 February 2005 


\title{
Trade Creation and Diversion Effects of Europe's Regional Liberalization Agreements
}

\author{
By \\ Yener Kandogan \\ University of Michigan-Flint
}

\author{
Running Title: Trade Creation and Diversion in Europe \\ Correspondence Address: \\ School of Management \\ University of Michigan-Flint \\ 303 E. Kearsley \\ Flint, MI 48502 \\ Phone: (810) 2376675 \\ Fax: (810) 7623282 \\ Email: yener@umich.edu
}




\title{
Trade Creation and Diversion Effects of
}

\section{Europe’s Regional Liberalization Agreements}

\begin{abstract}
After a short background on recent developments in gravity modelling and liberalization agreements in Europe, this paper measures the trade creation and diversion effects of major European agreements based on the results of a correctly specified triple-indexed gravity model with bilateral fixed effects. For each agreement and partner country, welfare implications are discussed in sectors of different factor intensities with emphasis on the role of similarity in income or relative factor endowments between partners, as well as the date and the reciprocity of the agreement. This is followed by a description of the characteristics of the non-partner countries that are affected by these agreements in each sector.
\end{abstract}

JEL Classification: F14, F15

Keywords: Gravity Model, Fixed Effects 


\section{Introduction}

Europe certainly has the most elaborate network of liberalization agreements among all regions of the world. These agreements are with a variety of different countries and they differ in the degree of integration intensity and the reciprocity of the liberalization process. This paper analyzes the trade creation and diversion effects of major regional liberalization agreements in Europe based on a modified triple-indexed gravity model. The agreements considered are the European Economic Area, the European Community's customs union, the agreements of European Free Trade Area countries, and those of the European Union countries, in particular, the Europe Agreements with Central and East European countries, the Euro-Mediterranean Agreements and the earlier Mediterranean Cooperation Agreements, as well as the Central European Free Trade Area.

Among others, Baldwin (1994), Feenstra (1998), Eichengreen and Irwin (1998) have shown that one of the most successful ways to formulize international trade flows is through gravitytype models. These models have been frequently used to measure the impact of regional trade agreements. Although since Viner (1950) it is known that the impact of any trade agreement is a combination of trade creation and diversion effects, gravity modellers rarely tried to decompose these effects (Greenaway and Milner, 2002). Some unsuccessfully tried to use dummy variables for members of trade blocs and for non-members, with the expectation of negative coefficients for the latter. However, this technique has been separately criticised by Polak (1996) and Matyas (1997) because of direct use of bloc dummy variables in the gravity equation, which, they conclude, leads to incorrect inferences. In fact, Matyas (1997) showed that such gravity models used for this purpose were actually mis-specified from the econometric point of view due to presence of unnecessary constraints put on the parameters of the model. They suggested a model with country fixed effects, which are to be analyzed to find the impact of liberalization agreements.

Taking these criticisms into account, this paper develops a methodology that captures trade creation and diversion effects using the parameters of a correctly-specified gravity model. The model is built on the triple-indexed gravity model, a fixed effects model with separate constants 
for the year, the importer and the exporter countries. This model is augmented by time-invariant bilateral interaction fixed effects, as well as some other factors that explain bilateral trade flows, except liberalization agreements. An analysis of error terms for member country importer and exporter pairs against those of a member country importer from non-member countries is carried out over time to capture trade creation and diversion effects of liberalization agreements.

The results show that majority of the liberalization agreements have been welfare improving for all partners involved in all sectors, especially in human and physical capital-intensive sectors. The exceptions are the Europe Agreements, and the Euro-Mediterranean Agreements, where the EU partners experienced welfare losses especially in resource- and labor-intensive sectors. While welfare gains are observed in EU's partners in the Europe Agreements across all sectors, the Euro-Mediterranean Agreements failed to create trade.

Largest diversions occurred from non-partner countries with similar income levels to partner countries, and also from former colonies, developing countries, and European countries that did not take part in these agreements, such as Norway and Switzerland.

The rest of the paper is organized as follows: After discussing the recent econometric developments in gravity modelling, a correctly specified fixed effects gravity model is proposed in Section 2 to decompose trade creation and diversion effects. A short background about the regional trade agreements in Europe precedes the application of the model to the trade of European countries in Section 3. Trade creation and diversion effects of agreements on different factor intensity sectors in partner countries are discussed along with an analysis of diversion from non-partner countries in Section 4.

\section{Background and the approach}

There are two broad options for governments seeking to liberalize trade: Unilateral and preferential liberalization. Both of these options lead to welfare improving trade creation: The removal of trade barriers leads to elimination of domestic sourcing by firms and consumers in some industries in favor of imports more efficiently produced in partner countries. However, Viner (1950) established that in contrast to unilateral liberalization, preferential liberalization give rise to both trade creation and diversion. In such agreements, since partner countries are favored, the possibility arises for trade diversion: The removal of trade barriers for partner 
countries may lead firms and consumers to source from less efficient suppliers located in a partner country rather than from the least-cost non-partner source of supply.

Although gravity models have been very frequently used in modelling international trade flows, they have not yet been successfully used in capturing the above-mentioned trade creation and diversion effects of liberalization agreements, despite the changes made since its development by Tinbergen (1962) and Poyhonen (1963). In its simplest form, the volume of bilateral trade between two countries is explained by the size of their economy, and the geographical distance between their economic centers. Trade-promoting variables that capture different aspects of bilateral relations often find their way into gravity models. Common border, common language, past colonial relations and measures of cultural proximity can be counted as the most frequently considered additions.

Furthermore, the basic model has also been augmented by monetary variables such as the real exchange rate (Bergstrand, 1985; Bayoumi and Eichengreen, 1995), and measures of exchange rate uncertainty as suggested by Thursby and Thursby (1987) such as foreign currency reserves (Matyas, 1997). Variables coming from competing trade theories are also often added to the model. Measures of relative factor endowments as suggested by the Heckscher-Ohlin Theory, and measures of similarity as suggested by the Increasing Returns Theory can be found in gravity models of Balassa (1986), Helpman (1987), and Balassa and Bauwens (1987).

Typically, bloc dummy variables were used in these models to test the significance of preferential agreements on trade volumes. Positive and significant coefficients for these bloc variables are interpreted as trade promoting effects of the agreements among partners in comparison to third countries. Raising econometric issues, Polak (1996) criticizes such use of bloc dummy variables directly in gravity models as the inferences they lead may be incorrect.

Some other econometric problems about the specification in the gravity models have also been recently raised. Wang and Winters (1991) argued against averaging models' variables over time since that would restrict the parameters of the model to be the same for every year. Similarly, Baldwin (1994) argued that using total trade as the dependent variable imposes an unnecessary constraint of equal coefficients for imports and exports. Matyas (1997) took this idea further to suggest that a correctly specified model should have separate constants not only for each year but also for each exporter and importer, proposing the triple-indexed gravity model. 
Lastly, Egger (2000), and Egger and Pfaffermayr (2003) removed another restriction by adding bilateral interaction fixed effects.

Taking all of these criticisms into account, the methodology used in this paper to capture trade creation and diversion effects is based on analyzing the error terms of the following correctly specified fixed effects gravity model:

$$
\begin{aligned}
M_{i j t}= & \lambda_{t}+\alpha_{i}+\gamma_{j}+\delta_{i j} \\
& \beta_{1} d_{i j}+\beta_{2 i} Y_{i t}+\beta_{2 j} Y_{j t}+\beta_{3 i} y_{i t}+\beta_{3 j} y_{j t}+ \\
& \beta_{4} \Delta e_{i j t}+\beta_{5 i} R_{i t}+\beta_{5 j} R_{j t}+ \\
& \beta_{6} S I M_{i j t}+\beta_{7} R F_{i j t}+ \\
& \beta_{8} C B_{i j}+\beta_{9} C L_{i j}+\beta_{10} C O L_{i j}+\phi_{i j t}
\end{aligned}
$$

where $M_{i j t}$ is country i's imports from country $j$ at time $t . \lambda_{t}, \alpha_{i}, \gamma_{j}$, and $\delta_{i j}$ are the year, the importer and exporter country, and bilateral interaction fixed effects, respectively. Year fixed effects capture time-varying factors that influences volume of imports for all countries. Importer and exporter country fixed effects take into account time-invariant factors specific to the importer and exporter countries. Lastly, bilateral interaction fixed effects bring in the timeinvariant influences for a country pair. Unlike Egger (2000) or Egger and Pfaffermayr (2003), a distinction is made here between the importer and exporter in the computation of bilateral fixed effects, since this allows for analysis of non-reciprocal trade agreements such as the Mediterranean Cooperation Agreements.

Furthermore, $d_{i j}$ stands for distance importer country $i$ and exporter country $j .{ }^{1}$ GDPs of importer and exporter countries, $Y_{i t}$ and $Y_{j t}$, their per capita GDPs, $y_{i t}$ and $y_{j t}$, as well as the real exchange rate $\Delta e_{i j t}$ and their foreign currency reserves, $R_{i t}$ and $R_{j t}$ are some of the other variables in the model.

Two variables in the model come from the competing trade theories: Similarity in economic sizes, $S I M_{i j t}$, and relative factor endowments, $R F_{i j t}$. These are computed as follows:

$$
S_{i j t}=\ln \left(1-\left(\frac{Y_{i t}}{Y_{i t}+Y_{j t}}\right)^{2}-\left(\frac{Y_{j t}}{Y_{i t}+Y_{j t}}\right)^{2}\right)
$$


captures the similarity in size of countries $i$ and $j$ at time $t$ in terms of their GDP. When the two countries are of equal size, the term inside the parentheses takes the value of 0.5 , and decreases as countries diverge in size.

$$
R F_{i j t}=\left|\ln \left(\frac{K_{i t}}{L_{i t}}\right)-\ln \left(\frac{K_{j t}}{L_{j t}}\right)\right|
$$

measures the distance between the partner countries in terms of their relative factor endowments. $K_{i t}$ and $L_{i t}$ denote the capital stock and the labor force for country $i$ at time $t$, respectively. When countries $i$ and $j$ have the same factor endowment ratios, this measure takes the value of zero, and increases as the difference widens. Capital stocks needed for the above measure is obtained using the perpetual inventory method:

$$
\begin{aligned}
& K_{i 1}=5\left(G F C F_{i 0}+G F C F_{i 1}\right) \\
& K_{i t}=0.9 K_{i t-1}+G F C F_{i t}
\end{aligned}
$$

where $G F C F_{i t}$ is the gross fixed capital formation in country $i$ at time $t$. Note that capital stocks are assumed to depreciate at a constant rate of $10 \%$.

Some bilateral factors that are typically used in the literature are also controlled. These are $C B_{i j}$, $C L_{i j}$, and $C O L_{i j}$, which capture the effects of common border, common language and past colonial relations, respectively. With the presence of these bilateral variables in the model, the error terms, $\phi_{i j t}$, are more refined, and can thus be interpreted as the time-variant bilateral effect on country i's imports from $j$ at time $t$, not taken into account elsewhere. In particular, the effects of liberalization agreements will predominantly be reflected on these error terms. Consequently, this gravity equation is used to benchmark normal levels of imports. The deviations from the normal captured by these time-varying bilateral error terms are analyzed over time to measure trade creation and diversion effects.

This model is regressed separately for imports from industries grouped based on the factor intensity of production (Wolfmayr-Schnitzer, 1998). The resulting five sectors are as follows: Resource-intensive industries (Sector 1), labor-intensive industries (Sector 2), human capitalintensive low technology industries (Sector 3), human capital-and labor-intensive high technology industries (Sector 4), and human and physical capital-intensive high technology industries (Sector 5). The list of SITC-2 codes of industries in each sector is given in Appendix A. Since 2002 was the last year with complete data set for all variables, the time period covered 
is 1962-2002. The analysis covers 42 partner countries' manufacturing trade with each other, and with 129 non-partner countries.

As one can see from the regression results given in Table 1, the parameters assumed the correct signs and are significant with the exception of relative factor endowment differences, $R F_{i j t}{ }^{2}$ Accordingly, imports of a country from another decrease with geographical distance between them, and increase with GDP and per capita GDP of both partners. Furthermore, increases in real exchange rate, measured by the price of foreign goods in terms of domestic good decreases imports, and stability of exchange rates, measured by foreign currency reserves, increases imports. However, note that the real exchange rate becomes an insignificant factor for all three human capital-intensive sectors. The usual trade-promoting impacts of common border, common language and colonial links are also observed. The unexpected negative sign for the difference in relative factor endowments can be explained by dominance intra-industry imports in Europe's imports. The majority of European trade is with other rich countries with similar factor endowments, making the Increasing Returns Theory more relevant for Europe's trade.

In the next section, the analysis of error terms of these regressions is carried out, after computing the year, importer and exporter country, and bilateral interaction fixed effects, which are not reported in Table 1.

\section{Europe's liberalization agreements}

Regional integration efforts in Europe started with formation of two blocs, the European Economic Community (now called the EU) in 1957, and the European Free Trade Area (EFTA) in 1960. European Economic Community provided a more intense integration than EFTA. It not only encompassed the gradual elimination of import barriers on all trade between member nations, but also for instituted common external tariffs.

In recent years, the EU engaged in a number of efforts to expand or deepen its trade relationships with neighboring countries. In fact, many consider granting trade preferences as the most effective foreign policy instrument of the EU (Brulhart and Matthews, 2003). These efforts took the form of the European Economic Area (EEA) with EFTA countries in 1994, the Europe Agreements (EA) with 10 Central and Eastern European Countries (CEEC) in the first half of 1990s. Some of the CEEC formed the Central European Free Trade Area (CEFTA) in 1993. 
Turkey entered into the European Community's Customs Union (ECCU) in 1996. The cooperation agreements of mid-1970s were transformed to eventually create the EuroMediterranean Free Trade Area (EMA) in 2010 under Association Agreements with a number of Mediterranean countries in late 1990s or early 2000s. EEA, EMA, and Turkey's accession to the ECCU can be considered in support of the suggestion of Lamy (2002) that the EU is now seeking to deepen rather than enlarge its regional trade agreements. The European Union also signed free trade agreements other than the EA and the EMA at various dates, which are grouped under the European Community’s - other- Free Trade Agreements (ECFTA). Similar agreements were also signed by EFTA with other countries of the region. List of the partner countries, the trade blocs, and the effective years of accession into these blocs are given in Table 2.

There are a number of similarities among these agreements. All aim at dismantling of trade barriers in manufacturing sectors, but no such goal is claimed for the agriculture or services industries. ${ }^{3}$ Furthermore, the liberalization process for all is asymmetric. In other words, the EU (or the EFTA) is scheduled to liberalize faster than their partners.

Some important differences should also be mentioned: Tariff elimination in EMA is more gradual than EA. The liberalization process is spread over a period of 8 years in the EAs as opposed to 12 years in EMAs. The intensity of the agreements is also different. The early cooperation agreements were nothing more than non-reciprocal preferential market access arrangements, which opened up the European markets to the partners, but a reciprocal liberalization was not expected from the partners. ${ }^{4}$ The Europe and the Mediterranean agreements aim on forming a free trade area, which involves reciprocal liberalization, although they are asymmetric in terms of liberalization process. The Customs Union agreement with Turkey is a result of reciprocal liberalization process dating back to 1963, which adopts common external tariffs. Lastly, the European Economic Area is the most intense form of liberalization, which also allows free movement of capital and labor.

Differences exist not only in the agreements but also in the characteristics of the partners involved. First of all, the CEEC, EFTA countries and Turkey are regarded as prospective members of the EU. ${ }^{5}$ In fact, these liberalization agreements ended with full membership for three former EFTA countries in 1995, and for all CEEC except Romania and Bulgaria in $2004{ }^{6}$ However, no such prospect exists of North African countries. To illustrate these differences, Table 3 gives the gross domestic product, per capita GDP, the capital-labor ratio of all countries 
of the region, the GDP-weighted distance of their economic centers to EU capitals, as well as the average tariff rates on the years the agreements came into force and for most recent years, computed using import duties as percentage of imports. These differences will also be crucial in assessing the trade creation and diversion impacts of the liberalization agreements, and also in determining which non-partner countries are going to be adversely affected.

With the exception of Luxembourg, all EU countries have big economies, with GDP's larger than 100 billion US\$. In this respect, EFTA countries are similar to EU countries, except for Iceland. Among CEEC, Poland is the only country comparable to the EU in terms of its size. This is also the case for Turkey, Israel, and Egypt to a lesser extent. The rest of the partners have significantly smaller economies. It is expected that liberalization agreements with bigger countries will have bigger impact, especially on smaller economies.

Weighted distances to EU capitals are less than $1000 \mathrm{~km}$ for the core EU countries. In Southern, Central and Eastern Europe, this distance is in 1000s of km, and between 2000-3000 $\mathrm{km}$ for Mediterranean partners. Liberalization with distant countries is expected to have smaller impact, since distance will present a non-tariff barrier to trade that can only be reduced with lower transport costs.

In terms of per capita incomes, there is no difference between EU and EFTA countries. The rest of the European partners' incomes are less than half of the EU average, with notable exceptions of the Czech Republic, Slovenia, Cyprus and Malta. The income levels in Mediterranean partners are much smaller except for Israel. There are also significant differences in capital-labor ratios of EU and EFTA members relative to other partners. The capital-labor ratio in CEEC is about $20 \%$ of that in the EU, ranging from $8 \%$ of the EU average in Latvia to $43 \%$ of the average in Slovenia. This ratio is comparable to Southern EU members in Cyprus, Malta, and Israel. However, for the rest of Europe and the Mediterranean countries, there is a large gap with the EU members ranging from 6\% to $15 \%$ of the EU average. Similarity in both income levels and capital-labor ratios will play an important role in determining which sectors will be most affected by a liberalization agreement between two countries, the magnitude of the impact, and from which non-partner countries trade will be diverted. Largest diversion is expected to be from countries with similar income or capital-labor ratios with the partner. The impact on human capital-intensive sectors is expected to be bigger in liberalizations with 
countries similar to EU, whereas liberalizations with low income or low capital-labor ratio countries will have bigger impact on resource- and labor-intensive sectors.

Average tariff rates were almost non-existent in EU countries and less than 2\% in EFTA countries at the time EEA was formed. The rate of tariff elimination in Ireland, Spain, Portugal, Iceland and Switzerland are especially remarkable. The tariff rates in CEEC were relatively low at the time of the EA, and are now at less than $2 \%$. In particular, Hungary, Poland, Slovenia, Romania and Bulgaria experienced the fastest liberalizations since the EA were signed. The average tariff rates dropped significantly in other Europe as well, as a result of the liberalization with the EU down to around 2\% in late 1990s. They are relatively higher in the remaining European countries, and significantly higher in Mediterranean countries, 6\% to 18\%, with the exception of Israel. Bigger reductions in average tariff rates over shorter periods of time are expected to have much bigger trade creation and diversion effects.

\section{Trade creation and diversion effects of Europe's agreements}

To compute the trade creation and diversion effects in a way that allows comparisons, for each agreement and each one of its members, the bilateral error terms from the regression model are averaged separately before and after the agreement for each of their partners in liberalization and non-partners. The sum of changes with partners after liberalization produced a measure of trade creation, and the one with non-partners is used to measure trade diversion effects. These changes are scaled so that the resulting figure gives these changes relative to importer country's GDP. Since 2002 was the last year covered in the analysis, countries that participated in an agreement after 2002 are considered non-partners.

The resulting trade creation and diversion effects are given in Table 4 for the EEA. Accordingly, only in Southern EU countries of Spain, Portugal, Greece, and to a lesser extent in Italy, the EEA led to trade creation with partners in labor- and resource-intensive sectors. In these sectors, majority of partner countries experienced increases in imports from non-partners. Spain was the only country with increases in imports from partners in human capital intensive low technology, and human capital- and labor-intensive sectors. Overall, the human and physical 
capital-intensive sector experienced the highest trade creation from the EEA. Interestingly, for the majority of the partners, the imports from non-partners also increased, implying that welfarereducing effects of trade diversion are not significant for this sector.

Similar changes are observed in Table 5, where the effects of ECCU are given. In addition to changes observed in Southern EU countries in Sectors 1-4, and those observed in almost all EU countries in human and physical capital-intensive sectors, trade creation is also observed in Sectors 1-4 in the core EU countries ${ }^{7}$, with no trade diversion effects from the non-partners. Sapir (1996) also finds that the increase in intra-EU trade was not at the expense of non-partners. For Turkey, trade creation is coupled with increases in imports from non-partners in all sectors. Hence, the welfare effects of ECCU on Turkey, the only non-EU member among the partners, seem positive across all sectors, with only slight trade diversion in human capital-intensive low technology sector.

Table 6 gives the effects of EFTA's agreements. Countries are grouped into two groups: Original members, and their partners that made agreements with EFTA mostly in 1990s. EFTA's agreements seem to be welfare improving for all of the original members in all sectors. Imports from partners have increased along with small but positive changes with non-partners. Only a few countries experienced decreases in their imports from partners in resource- and laborintensive sectors. The distant country of Iceland stands out in this group, which has seen its imports from both partners and non-partners decrease for most sectors. The situation in new partners of EFTA shows the effect of date of liberalization. The changes in imports from both partners and non-partners are mostly positive and are much bigger than the changes observed in most recent partners, which are mostly negative. It is also worth mentioning that EFTA's agreements resulted in bigger magnitude changes in new partners than in the original members. This might be a combined result of income or capital-labor ratio and size differences between these two groups.

Somewhat similar effects are observed as a result of the European Community's agreements other than EA and EMA, given in Table 7. Especially for the core EU countries, welfare implications are positive with increases in imports from both partners and non-partners in all sectors. However, for other EU countries and for the new partners of the EU, there are some decreases in resource-intensive, labor-intensive, and human capital-intensive low technology sectors, more so with partners than with non-partners. Like in the case of EFTA's agreements, 
the effects on new partners of the EU are much bigger in magnitude. In most recent partners, there are decreases in imports from both partners and non-partners in all sectors.

Interesting conclusions can be drawn from the effects of Europe Agreements shown in Table 8. For an overwhelming majority of the EU members, Europe Agreements resulted in welfare losses in Sectors 1-4; imports from partners have increased while it suffered from decreases in imports from non-partners. Only the changes in the human and physical capitalintensive high technology sector are welfare improving with increases in imports from both partners and non-partners for most EU members. In contrast, the CEEC partners experienced welfare gains in all sectors. Furthermore, the increases in imports from partners and non-partners are both more pronounced than those experienced by EU members. The most recent partner, Slovenia, constitutes the only exception, which experienced decreases in imports from both partners and non-partners in most sectors. Slovenia also stands out in the effects of CEFTA as well, given in Table 9. It is also the only country that experienced welfare loses from CEFTA, where increases in imports from partners were primarily a consequence of decreases of imports from non-partners. For other CEEC, the increases in imports from partners were accompanied by much larger increases with non-partners in all sectors, yielding welfare gains for them.

The effects of early non-reciprocal cooperation agreements with Mediterranean countries and the Euro-Mediterranean agreements are given in Tables 10 and 11. Accordingly, the cooperation agreements have been welfare reducing for EU countries in the resource-intensive sectors, and welfare improving in human and physical capital intensive high technology sectors. While the same effects resulted from the EMA, the effect on Sectors 2-4 have been different for these agreements: Cooperation agreements yielded mixed results, but EMAs were welfare reducing for these sectors. The effects on Mediterranean partners' imports show that both the cooperation agreements and the EMAs have been unsuccessful in trade creation. Imports of these countries from partners have been negatively affected, while imports from non-partners have somewhat increased with the exception of Sectors 3 and 4 where there are decreases. While this implies no welfare losses due to an overall insignificant trade diversion, lack of trade creation implies no welfare gains either. Non-reciprocality of the cooperation agreements is likely to be the reason for absence of increase in imports of Mediterranean countries from their EU partners. However, due its reciprocity, the result in EMAs can only be explained by their very recent enforcement. 
Furthermore, large trade diversions were expected in Mediterranean countries' imports as a result of EMAs (Hoekman and Djankov, 1996). Since the European countries had already opened their markets through the early cooperation agreements, the EMAs only opened up Mediterranean markets to European countries. Expected trade diversion in Mediterranean imports has so far occurred only in Sectors 3 and 4. Hoekman and Djankov (1996) give incentives to reforms, commitment to market economy rules, and enforcement mechanisms as possible reasons for why Mediterranean countries would agree to these clearly-welfare reducing EMAs.

Other than the partner countries, the impact on non-partners is also worthwhile to examine. An interesting question to analyze is how similarity in income levels of non-partner countries with levels in partner countries plays a role in determining the degree of diversion from nonpartners in different factor intensity sectors. To analyze this, Figure 1 shows the relationship between per capita income levels in non-partners and trade diversion in these countries for each of the sectors as a result of all of the agreements considered in this paper. The degree of diversion reported here is with respect to non-partner exporter country's GDP, rather than importer partner's GDP that has previously been the case.

First note that, in the figures there are some partner countries that have been analyzed earlier. This is because countries are considered non-partners in the agreements that they did not take part. For example, EFTA countries are non-partners in ECCU, EA, CEFTA, EMA, and MCA. Furthermore, even if not shown here, since the analysis is on non-partners, there is also considerable diversion effect on new partnerships on old partners. In fact, that is quite significant in EEA and ECCU, where income similarity is high between old and new partners.

In Figure 1, first note that largest diversions have occurred in resource-intensive sector, and moderate diversions are observed in the labor-intensive sector. Trade diversions in all three human capital-intensive sectors have been less than $0.1 \%$ of the non-partners GDP, with the exception of couple countries in Sector $5 .^{8}$ While, there is clearly more diversion from poorer non-partners in resource-intensive sectors, diversion from richer countries is notable in human capital intensive sectors 3 and 4. In the labor-intensive sector, and to some degree in human capital and labor intensive sector, middle-income developing countries have experienced decreases in their exports to European countries as well. Overall, the diversion has occurred from former colonies of the UK, Netherlands and France, from other developing countries such as 
Chile, Hong Kong, Korea, as well as some rich European non-partners, notably from Norway and Switzerland.

It is also noteworthy that there is a general positive correlation with the magnitude of trade diversion and per capita income levels.

Figure 2 gives similar plots separately for each agreement but aggregated over all sectors. Largest trade diversions occurred as a result of ECFTA, EA, and EMA, ignoring the diversion from the outlier non-partner country of Zambia. The average diversion due to these agreements is about $0.1 \%$ of the non-partner countries' GDP. Note that these are the agreements where the similarity in income levels or relative factor endowments between the EU and its partners were the largest. The same is the case for EMA, but the lower than expected diversion due to EMA is likely a result of very recent dates of EMA. Moderate diversions have occurred as a result of EEA and ECCU where, income levels are similar among the partners. EFTA and especially CEFTA resulted in the smallest trade diversion, around $0.005 \%$ of non-partners' GDP, possibly due to smaller scale of the agreements in terms of the number and size of the partners involved. As observed in Figure 1, the effects have been primarily on exports of former European colonies, developing countries, and Norway and Switzerland. It is also noteworthy that trade diversion due

to EFTA impacted primarily the neighboring non-partner East European countries such as Ukraine, Belarus, Moldova, Russia and Kazakhstan. Similarly, nearby countries of Macedonia, Moldova, Belarus and Lithuania are impacted most by CEFTA.

\section{Conclusion}

This paper developed a modified version of the triple-indexed gravity model with bilateral interaction fixed effects, and analyzed its time-varying bilateral error terms to measure trade creation and diversion effects of major European liberalization agreements.

The majority of the agreements turn out to be welfare improving for the European and its partner countries in all factor intensity sectors. The exceptions are the liberalization agreements made with less similar partners such as the Europe Agreements with Central and East European countries, and the Euro-Mediterranean Agreements with Southern Mediterranean countries, especially in resource- and labor-intensive sectors. While the EU's partners in the Europe Agreements experienced welfare-improvements, the latter agreement was ineffective to improve the welfare of the EU's partners because of its failure to create trade. 
A few observations are worth stressing. The impact, either the trade creation or diversion is bigger on smaller partners. This is especially obvious in EEA, where the date of enforcement is the same, and the income or capital-labor ratios are similar among partners. Secondly, date of enforcement matters. The impact of an agreement is much smaller, and typically more welfare improving for old partners relative to larger and generally non-trade creating for newer partners. This can be observed when comparing the core EU members to countries that joined the EU in 1995 in ECCU and ECFTA agreements, and when comparing the EU members to its partners in EA and EMAs.

Lastly, similarity in income or capital-labor ratios seem to be relevant in determining which partner countries will experience trade creation in which sectors, and which non-partners will be hurt by the trade diversion. Southern EU countries experienced the trade creation in resourceand labor-intensive sectors, whereas for the rest the impact on human and physical capitalintensive sectors was most significant as a result of ECCU and EEA. Another example came from the Europe Agreements, where trade creation was most significant in the first two sectors for CEEC, and in the latter for the EU.

Largest diversions occurred as a result of ECFTA, EA and MCA, where there are large differences in terms of income and capital-labor ratios between the EU countries and their partners. Furthermore, diversion typically occurred from non-partners from former colonies and developing countries, which are somewhat similar to EU's partners in these agreements. This is reflected in significant positive correlation between income and measure of diversion.

The diversion from Norway and Switzerland is noteworthy, given their similarity to the EU countries. These countries willingly excluded themselves from the EU. Although not conclusive, this finding raises the possibility of a domino effect of the EU's agreements, and might force these countries to reconsider their decision or to liberalize their trade separately with the EU's partners in these agreements. Similar expectations exist for former Soviet countries of Ukraine, Belarus, Kazakhstan and the Russian Federation given the effects of EFTA, and for Macedonia, Moldova, and Belarus given the effects of CEFTA. Using the gravity approach of this paper for these countries and agreements might provide further evidence for the domino effects theory by Greenaway (2000) and Sapir (2001). 


\section{Acknowledgments}

Financial support provided for this research by the University of Michigan, Ann Arbor, Rackham Faculty Grant and Fellowship Program is gratefully appreciated by the author.

\section{References}

Balassa, Bela (1986). "The Determinants of Intra-Industry Specialization in the United States Trade.” Oxford Economic Papers 38, 220-233.

Balassa, Bela, and Luc Bauwens (1987). “Intra-Industry Specialization in a Multi-Country and Multi-Industry Framework.” The Economic Journal 97, 923-939.

Baldwin, Richard (1994). Towards an Integrated Europe. Centre for Economic Policy Research, London.

Bayoumi, Tamim, and Barry Eichengreen (1995). “Is Regionalism Simply a Diversion? Evidence from the Evolution of the EC and EFTA.”NBER Working Paper 5283.

Bergstrand, Jeffrey (1985). “The Gravity Equation in International Trade: Some Microeconomic Foundations, and Empirical Evidence.” Review of Economics and Statistics 67, 474-481.

Brulhart, Marius and Alan Matthews (2003). “External Trade Policy.” In The European Union: Economics and Politics, edited by Ali El-Agraa, Prentice Hall.

Egger, Peter (2000). “A Note on the Proper Econometric Specification of the Gravity Equation.” Economic Letters 66, 25-31.

Egger, Peter, and Michael Pfaffermayr (2003). “The Proper Panel Econometric Specification of the Gravity Equation: A Three Way Model with Bilateral Interaction Effects.” Empirical Economics 28, 571-580.

Eichengreen, Barry, and Douglas Irwin (1998). “The Role of History in Bilateral Trade Flows.”

In The Regionalization of the World Economy, edited by Jeffrey Frankel, The University of Chicago Press, Chicago.

Feenstra, Robert (1998). "Integration of trade and Disintegration of Production in the Global Economy.” Journal of Economic Perspectives 12, 31-50.

Frankel, Jeffrey, Ernesto Stein, and Shang-jin Wei (1995). "Trading Blocs and the Americas:

The Natural, the Unnatural, and the Supernatural.” Journal of Development Economics 47, 61-95. 
Greenaway, David (2000). “Multilateralism, Minilateralism, and Trade Expansion.” In Asian Exports, edited by D. Das, Oxford University Press, Oxford.

Greenaway, David and Chris Milner (2002). "Regionalism and Gravity.” Leverhulme Centre Research Paper 2002/20.

Helpman, Elhanan (1987). "Imperfect Competition and International Trade: Evidence from Fourteen Industrial Countries.” Journal of Japanese and International Economics 1, 62-81.

Hoekman, Bernard, and Simeon Djankov (1996). "Catching Up with Eastern Europe? The European Union's Mediterranean Free Trade Initiative.” World Bank Policy Research Working Paper 1562.

Lamy, Pascal (2002). "Stepping Stones or Stumbling Blocks? The EU's Approach Towards the Problem of Multilateralism vs Regionalism in Trade Policy.” The World Economy 25, 13991413.

Matyas, Laszlo (1997). "Proper Econometric Specification of the Gravity Model.” The World Economy 20, 363-368.

Polak, Jacques (1996). "Is APEC a Natural Regional trading Bloc? A Critique of the Gravity Model of International Trade.” The World Economy 19, 533-543.

Poyhonen, Pentty (1963). "A Tentative model for Volume in Trade Between Countries." Weltwirtschaftliches Archiv 90, 91-113.

Sapir, Andre (1996). "The Effects of Europe’s Internal Market Programme on Production and Trade: A First Assessment.” Weltwirtschaftliches Archiv 132, 457-475.

Sapir, Andre (2001). "Domino Effects in Western European Regional Trade 1960-1992.” European Journal of Political Economy 17, 377-388.

Thursby, Jerry and Marie Thursby (1987). "Bilateral Trade Flows, the Linder Hypothesis and Exchange Risk." Review of Economics and Statistics 69, 488-495.

Tinbergen, Jan (1962). Shaping the World Economy. Twentieth Century Fund, New York. Viner, Jacob (1950). The Customs Union Issue. Carnegie Endowment for International Peace, New York.

Wang, Zhen Kun, and Alan Winters (1991). “The Trading Potential of Eastern Europe.” CEPR Discussion Paper 610.

Wolfmayr-Schnitzer, Yvonne (1998). "Trade Performance of CEECs According to Technology Classes.” In The Competitiveness of Transition Economies. OECD Proceedings 81-92. 
TABLE 1. Regression results for each sector

\begin{tabular}{|c|c|c|c|c|c|}
\hline$M_{i j t}$ & (1) & (2) & (3) & (4) & (5) \\
\hline \multirow[t]{2}{*}{$\overline{d_{i j}}$} & -1.33 & -1.24 & -1.10 & -1.10 & -1.12 \\
\hline & $(-120)$ & $(-126)$ & $(-87.1)$ & $(-92.3)$ & $(-95.5)$ \\
\hline \multirow[t]{2}{*}{$Y_{i t}$} & 0.32 & 0.38 & 0.37 & 0.36 & 0.31 \\
\hline & (18.5) & (25.6) & (18.9) & (19.2) & (16.6) \\
\hline \multirow[t]{2}{*}{$Y_{j t}$} & 0.09 & -0.09 & 0.23 & 0.15 & 0.06 \\
\hline & $(5.02)$ & $(-5.80)$ & (9.95) & $(6.82)$ & $(2.75)$ \\
\hline \multirow{2}{*}{$y_{i t}$} & 0.47 & 0.58 & 0.74 & 0.83 & 0.59 \\
\hline & (20.7) & (29.9) & (29.4) & (34.8) & $(24.1)$ \\
\hline \multirow[t]{2}{*}{$y_{j t}$} & 0.63 & 0.68 & 1.01 & 0.96 & 0.91 \\
\hline & (24.7) & (31.5) & (32.6) & (33.4) & (29.1) \\
\hline \multirow[t]{2}{*}{$\Delta e_{i j t}$} & -0.00002 & -0.00002 & -0.00001 & -0.00001 & -0.00001 \\
\hline & $(-2.44)$ & $(-2.50)$ & $(-1.13)$ & $(-1.69)$ & $(-0.99)$ \\
\hline \multirow[t]{2}{*}{$R_{i t}$} & 0.05 & 0.12 & 0.04 & 0.09 & 0.04 \\
\hline & (8.47) & (25.7) & (7.16) & (15.6) & (6.91) \\
\hline \multirow[t]{2}{*}{$\boldsymbol{R}_{j t}$} & 0.08 & 0.14 & 0.07 & 0.15 & 0.08 \\
\hline & (13.6) & (27.9) & (8.89) & (21.9) & $(11.2)$ \\
\hline \multirow[t]{2}{*}{$S I M_{i j t}$} & 0.17 & 0.01 & -0.02 & -0.01 & 0.06 \\
\hline & (31.9) & (1.19) & $(-2.45)$ & $(-2.06)$ & (10.0) \\
\hline \multirow[t]{2}{*}{$R F_{i j t}$} & -0.16 & -0.01 & -0.09 & -0.04 & -0.07 \\
\hline & $(-26.3)$ & $(-1.96)$ & $(-11.3)$ & $(-5.92)$ & $(-10.2)$ \\
\hline \multirow[t]{2}{*}{$C B_{i j}$} & 0.28 & 0.18 & 0.18 & 0.34 & 0.31 \\
\hline & (11.5) & (7.78) & (6.36) & (12.7) & (12.3) \\
\hline \multirow[t]{2}{*}{$C L_{i j}$} & 0.26 & 0.55 & 0.37 & 0.34 & 0.41 \\
\hline & (19.1) & $(47.4)$ & (24.1) & $(23.0)$ & (27.3) \\
\hline \multirow[t]{2}{*}{$C O L_{i j}$} & 0.89 & 0.70 & 0.72 & 0.68 & 0.41 \\
\hline & (33.8) & (32.4) & (23.7) & (23.9) & (27.3) \\
\hline
\end{tabular}

Notes: Numbers in parentheses are t-statistics.

Sector 1: Resource-intensive, 2: Labor-intensive 3: Human capitalintensive low technology, 4: Human capital- and labor-intensive high technology, 5: Human and physical capital-intensive high technology.

Data source: UN Comtrade, World Development Indicators 2004, IMF International Financial Statistics, and CEPII. 
TABLE 2. Trade agreements of Europe

\begin{tabular}{|c|c|c|c|c|c|c|c|c|c|}
\hline Country & Code & EEA & ECCU & EFTA & ECFTA & EA & CEFTA & MCA & EMA \\
\hline Algeria & $\mathrm{DZ}$ & - & - & - & - & - & - & 1976 & 2002 \\
\hline Austria & AT & 1994 & 1995 & $1960 *$ & 1973 & - & - & - & - \\
\hline Belgium & $\mathrm{BE}$ & 1994 & 1957 & - & 1957 & - & - & - & - \\
\hline Bulgaria & BG & - & - & 1993 & - & 1993 & 1999 & - & - \\
\hline Croatia & HR & - & - & 2002 & 2002 & - & 2003 & - & - \\
\hline Cyprus & CY & 2004 & 2004 & - & 1973 & - & - & - & - \\
\hline The Czech Rep. & $\mathrm{CZ}$ & 2004 & 2004 & 1992 & - & 1992 & 1993 & - & - \\
\hline Denmark & DK & 1994 & 1973 & $1960 *$ & 1973 & - & - & - & - \\
\hline Egypt & EG & - & - & - & - & - & - & 1977 & 2004 \\
\hline Estonia & $\mathrm{EE}$ & 2004 & 2004 & 1996 & - & 1995 & - & - & - \\
\hline Finland & FI & 1994 & 1995 & $1986^{*}$ & 1973 & - & - & - & - \\
\hline France & FR & 1994 & 1957 & - & 1957 & - & - & - & - \\
\hline Germany & $\mathrm{DE}$ & 1994 & 1957 & - & 1957 & - & - & - & - \\
\hline Greece & GR & 1994 & 1981 & - & 1981 & - & - & - & - \\
\hline Hungary & $\mathrm{HU}$ & 2004 & 2004 & 1993 & - & 1992 & 1993 & - & - \\
\hline Iceland & IS & 1994 & - & 1970 & 1973 & - & - & - & - \\
\hline Ireland & IE & 1994 & 1973 & $1960 *$ & 1973 & - & - & - & - \\
\hline Israel & IL & - & - & 1993 & - & - & - & - & 2000 \\
\hline Italy & IT & 1994 & 1957 & - & 1957 & - & - & - & - \\
\hline Jordan & JO & - & - & 2002 & - & - & - & 1977 & 2002 \\
\hline Latvia & $\mathrm{LV}$ & 2004 & 2004 & 1996 & - & 1995 & - & - & - \\
\hline Lebanon & LB & - & - & - & - & - & - & 1977 & 2003 \\
\hline Lithuania & $\mathrm{LT}$ & 2004 & 2004 & 1996 & - & 1995 & - & - & - \\
\hline Luxembourg & $\mathrm{LU}$ & 1994 & 1957 & - & 1957 & - & - & - & - \\
\hline FYR Macedonia & MK & - & - & 2001 & 2001 & - & - & - & - \\
\hline Malta & MT & 2004 & 2004 & - & 1971 & - & - & - & - \\
\hline Morocco & MA & - & - & 1999 & - & - & - & - & 2000 \\
\hline Netherlands & NL & 1994 & 1957 & - & 1957 & - & - & - & - \\
\hline Norway & NO & 1994 & - & 1960 & 1973 & - & - & - & - \\
\hline Palestine & PS & - & - & 1999 & - & - & - & - & 1997 \\
\hline Poland & PL & 2004 & 2004 & 1993 & - & 1992 & 1993 & - & - \\
\hline Portugal & $\mathrm{PT}$ & 1994 & 1986 & $1960 *$ & 1973 & - & - & - & - \\
\hline Romania & RO & - & - & 1993 & - & 1993 & 1997 & - & - \\
\hline The Slovak Rep. & . SK & 2004 & 2004 & 1992 & - & 1992 & 1993 & - & - \\
\hline Slovenia & SI & 2004 & 2004 & 1995 & - & 1997 & 1996 & - & - \\
\hline Spain & ES & 1994 & 1986 & - & 1986 & - & - & - & - \\
\hline Sweden & $\mathrm{SE}$ & 1994 & 1995 & $1960 *$ & 1973 & - & - & - & - \\
\hline Switzerland & $\mathrm{CH}$ & 1994 & - & 1960 & 1973 & - & - & - & - \\
\hline Syria & SY & - & - & - & - & - & - & 1977 & - \\
\hline Tunisia & $\mathrm{TN}$ & - & - & - & - & - & - & - & 1998 \\
\hline Turkey & TR & - & 1996 & 1992 & 1963 & - & - & - & - \\
\hline The UK & UK & 1994 & 1973 & $1960 *$ & 1973 & - & - & - & - \\
\hline
\end{tabular}

Notes: Dates of entry into force of accession agreements into blocs for individual countries are shown. Countries with * later withdrew from EFTA to join ECCU.

Data source: EU External Trade Commission. 
TABLE 3. Some characteristics of the European countries and their partners

\begin{tabular}{|c|c|c|c|c|c|c|}
\hline Country & GDP & DIST & PCGDP & K/L & average tariffs & \\
\hline Belgium & 260.3 & 720 & 26,960 & 93,304 & $0.33(1973)-0.00(1994)$ & \multirow{15}{*}{ 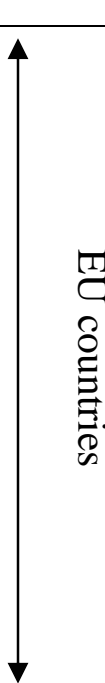 } \\
\hline Luxembourg & 25.0 & 716 & 55,100 & 158,018 & $0.07(1973)-0.00(1994)$ & \\
\hline Netherlands & 393.0 & 765 & 27,206 & 87,241 & $0.49(1973)-0.00(1994)$ & \\
\hline France & 1391.2 & 775 & 25,122 & 84,351 & $0.51(1973)-0.01(1994)$ & \\
\hline Germany & 1992.0 & 890 & 25,810 & 90,197 & $0.57(1973)-0.00(1994)$ & \\
\hline Italy & 1145.6 & 1132 & 24,808 & 70,333 & $0.49(1973)-0.01(1994)$ & \\
\hline The UK & 1463.5 & 844 & 24,524 & 58,331 & $1.50(1973)-0.00(1994)$ & \\
\hline Ireland & 100.3 & 1194 & 29,940 & 73,432 & $10.68(1973)-0.00(1994)$ & \\
\hline Denmark & 167.2 & 1026 & 28,958 & 86,960 & $1.21(1973)-0.00(1994)$ & \\
\hline Greece & 120.9 & 1921 & 16,704 & 41,740 & 6.98(1973) - 0.05(1994) & \\
\hline Spain & 597.5 & 1400 & 19,864 & 58,748 & $13.42(1973)-0.01(1994)$ & \\
\hline Portugal & 113.1 & 1782 & 17,092 & 38,945 & $8.03(1973)-0.01(1994)$ & \\
\hline Austria & 201.3 & 993 & 27,618 & 101,097 & $4.51(1973)-1.21(1994)$ & \\
\hline Finland & 126.1 & 1776 & 24,606 & 82,394 & $3.03(1973)-0.97(1994)$ & \\
\hline Sweden & 239.9 & 1468 & 24,188 & 76,434 & $1.73(1973)-0.95(1994)$ & \\
\hline Iceland & 8.2 & 2482 & 28,244 & 78,273 & $20.04(1973)-1.28(1994)$ & \\
\hline Norway & 167.1 & 1373 & 34,900 & 111,427 & $1.22(1973)-0.69(1994)$ & \\
\hline Switzerland & 254.8 & 790 & 28,436 & 118,790 & $7.17(1973)-0.79(1994)$ & \\
\hline The Czech Rep.* & 58.0 & 880 & 14,186 & 21,616 & $2.79(1992)-0.63(2001)$ & \multirow{10}{*}{$\begin{array}{l}\Omega \\
\text { T. } \\
\text { M } \\
\Omega\end{array}$} \\
\hline The Slovak Rep.* & 21.2 & 1031 & 11,578 & 17,904 & $2.79(1992)-0.47(2001)$ & \\
\hline Slovenia* & 20.0 & 979 & 16,588 & 35,355 & $6.15(1995)-1.07(2001)$ & \\
\hline Hungary* & 51.9 & 1147 & 12,178 & 16,871 & $10.74(1992)-1.11(2001)$ & \\
\hline Poland* & 170.0 & 1229 & 9,786 & 11,636 & $15.50(1992)-1.70(2001)$ & \\
\hline Estonia* & 5.5 & 1718 & 10,406 & 14,801 & $0.19(1995)-0.04(2001)$ & \\
\hline Latvia* & 7.2 & 1554 & 7,764 & 7,134 & $1.58(1995)-0.57(2001)$ & \\
\hline Lithuania* & 11.7 & 1531 & 8,996 & 12,976 & $1.20(1995)-0.50(2001)$ & \\
\hline Bulgaria & 13.5 & 1593 & 6,258 & 7,395 & $4.79(1995)-1.04(2001)$ & \\
\hline Romania & 40.1 & 1684 & 5,914 & 7,797 & $5.41(1993)-1.89(2001)$ & \\
\hline Cyprus* & 9.3 & 2721 & 16,937 & 36,168 & $5.42(1975)-2.32(1998)$ & \multirow{5}{*}{ 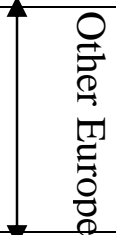 } \\
\hline Malta* & 3.6 & 1704 & 16,878 & 45,181 & $12.90(1972)-1.45(1998)$ & \\
\hline Turkey & 182.3 & 2040 & 6,070 & 9,971 & $32.84(1970)-1.56(1996)$ & \\
\hline FYR Macedonia & 3.6 & 1524 & 6,294 & 7,338 & N.A. $-4.56(2002)$ & \\
\hline Croatia & 20.4 & 1049 & 9,232 & 14,424 & N.A. $\quad-4.75(2001)$ & \\
\hline Egypt & 91.8 & 3004 & 3,514 & 4,457 & $20.11(1977)-12.78(1997)$ & \multirow{9}{*}{ 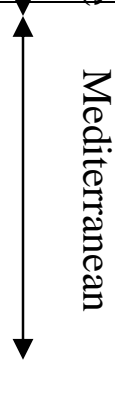 } \\
\hline Algeria & 51.8 & 1531 & 5,400 & 12,412 & N.A. $\quad-17.88(2001)$ & \\
\hline Israel & 107.0 & 3048 & 19,512 & 56,489 & $0.83(1993)-0.62(2000)$ & \\
\hline Jordan & 8.5 & 3133 & 3,970 & 10,514 & $13.70(1977)-5.66(2001)$ & \\
\hline Lebanon & 16.7 & 2957 & 4,262 & 15,149 & N.A. $\quad-14.60(1999)$ & \\
\hline Morocco & 34.9 & 2075 & 3,580 & 5,112 & $-13.89(1999)$ & \\
\hline Palestine & 4.1 & 3072 & 1,389 & 7,263 & N.A. $\quad-\quad$ N.A. & \\
\hline Syria & 17.9 & 3038 & 3,440 & 5,728 & $10.78(1977)-6.23(1999)$ & \\
\hline Tunisia & 20.2 & 1525 & 6,228 & 9,965 & $8.40(1998)-6.82(2000)$ & \\
\hline
\end{tabular}

Notes: Countries with * later joined the EU. GDP and per capita GDP are averages for 1998-2002 in terms of purchasing power parity. GDP is in billions of US\$. Capital-labor ratios are in US\$ per worker. 1973 and 2001 are the earliest and latest observations for average tariff rates for most countries.

Data source: World Development Indicators 2004, CEPII, and the author's own calculations. 


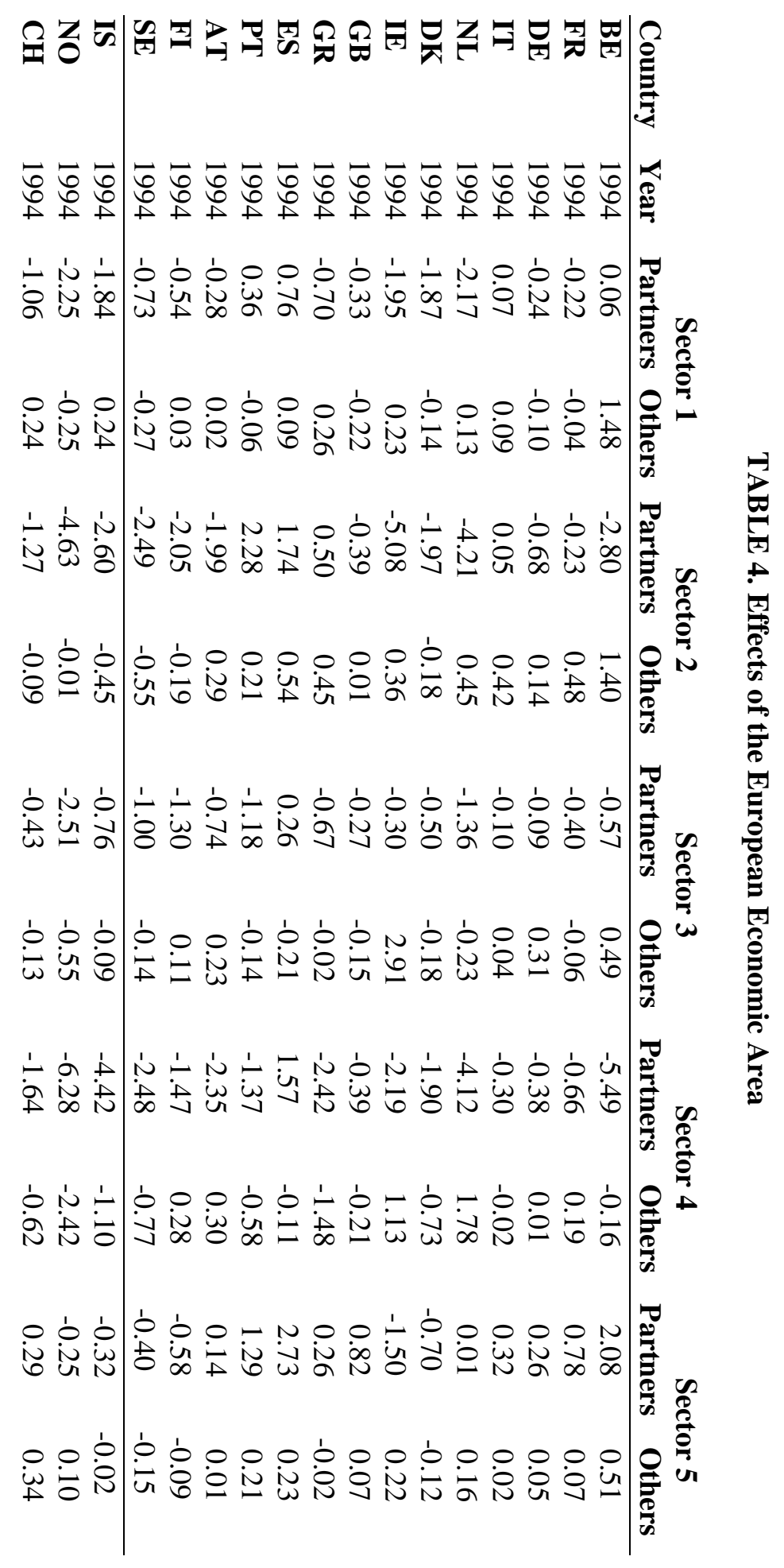




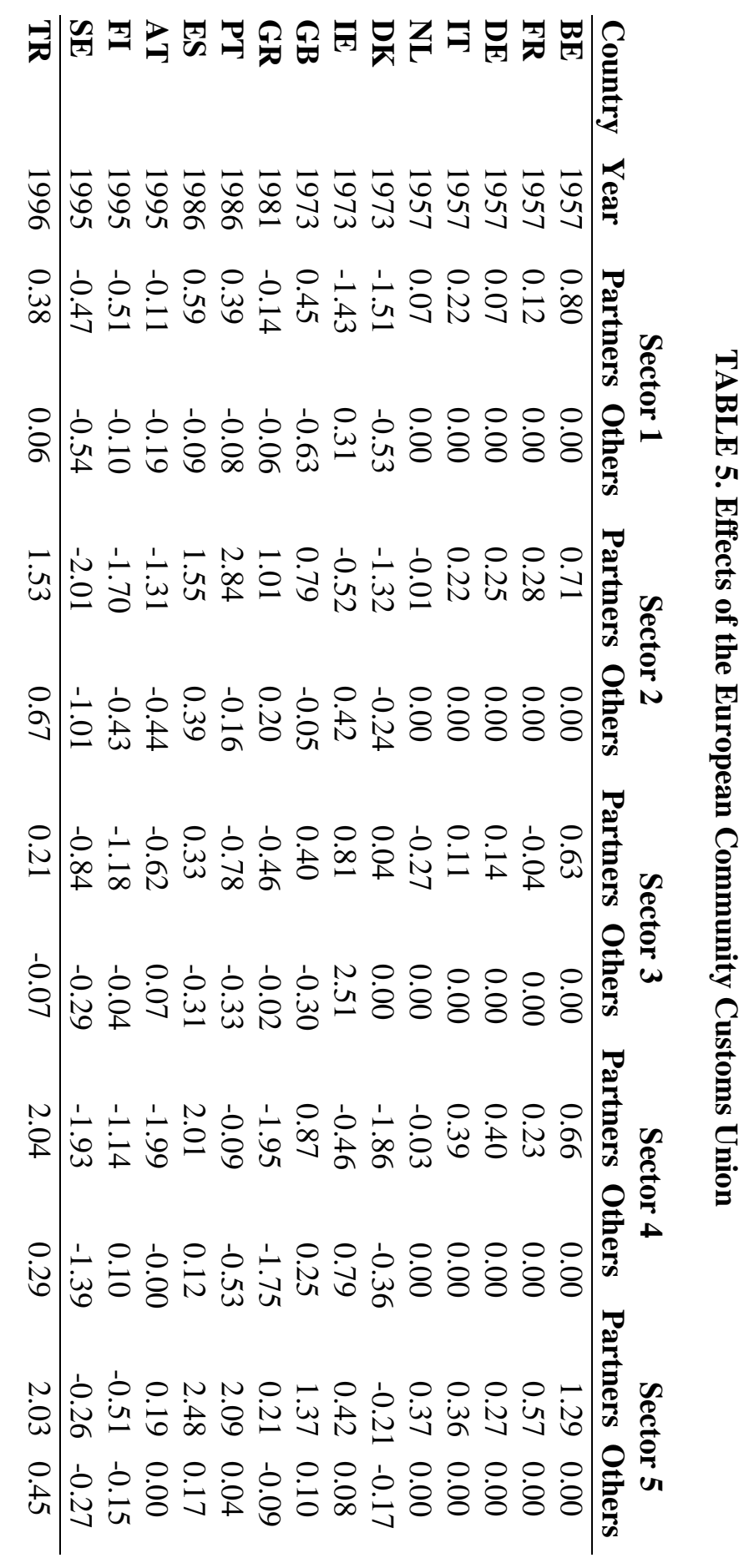




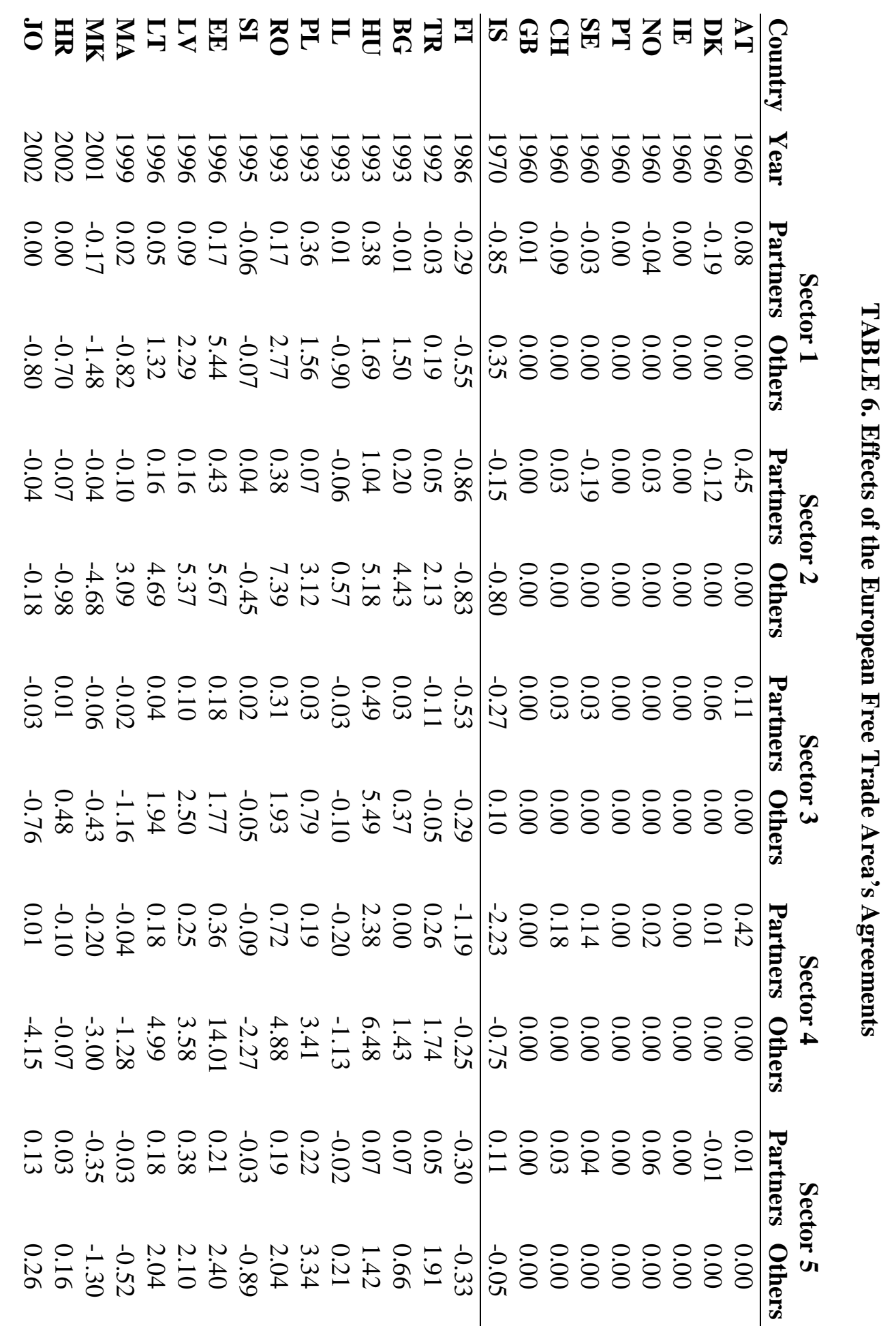




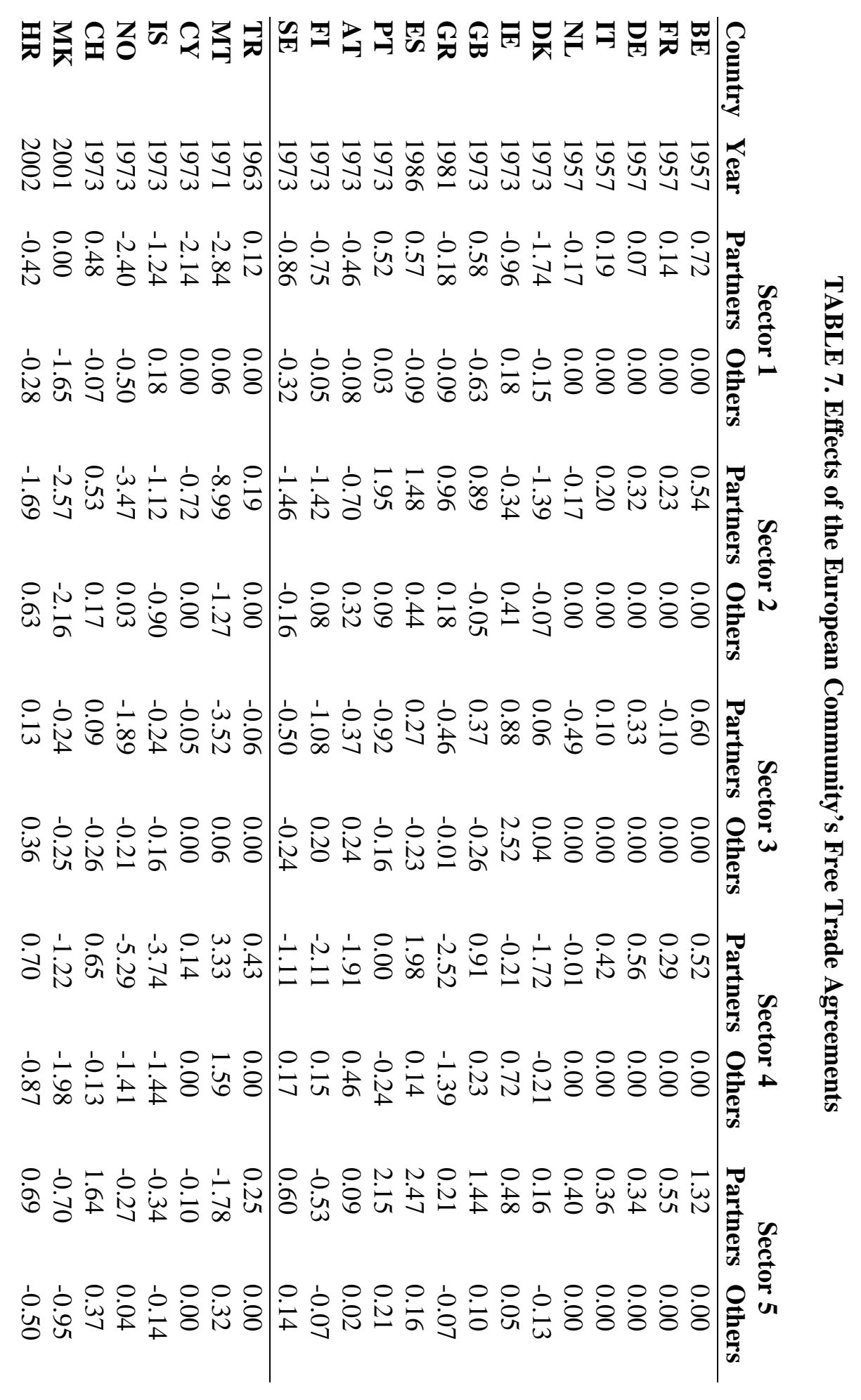




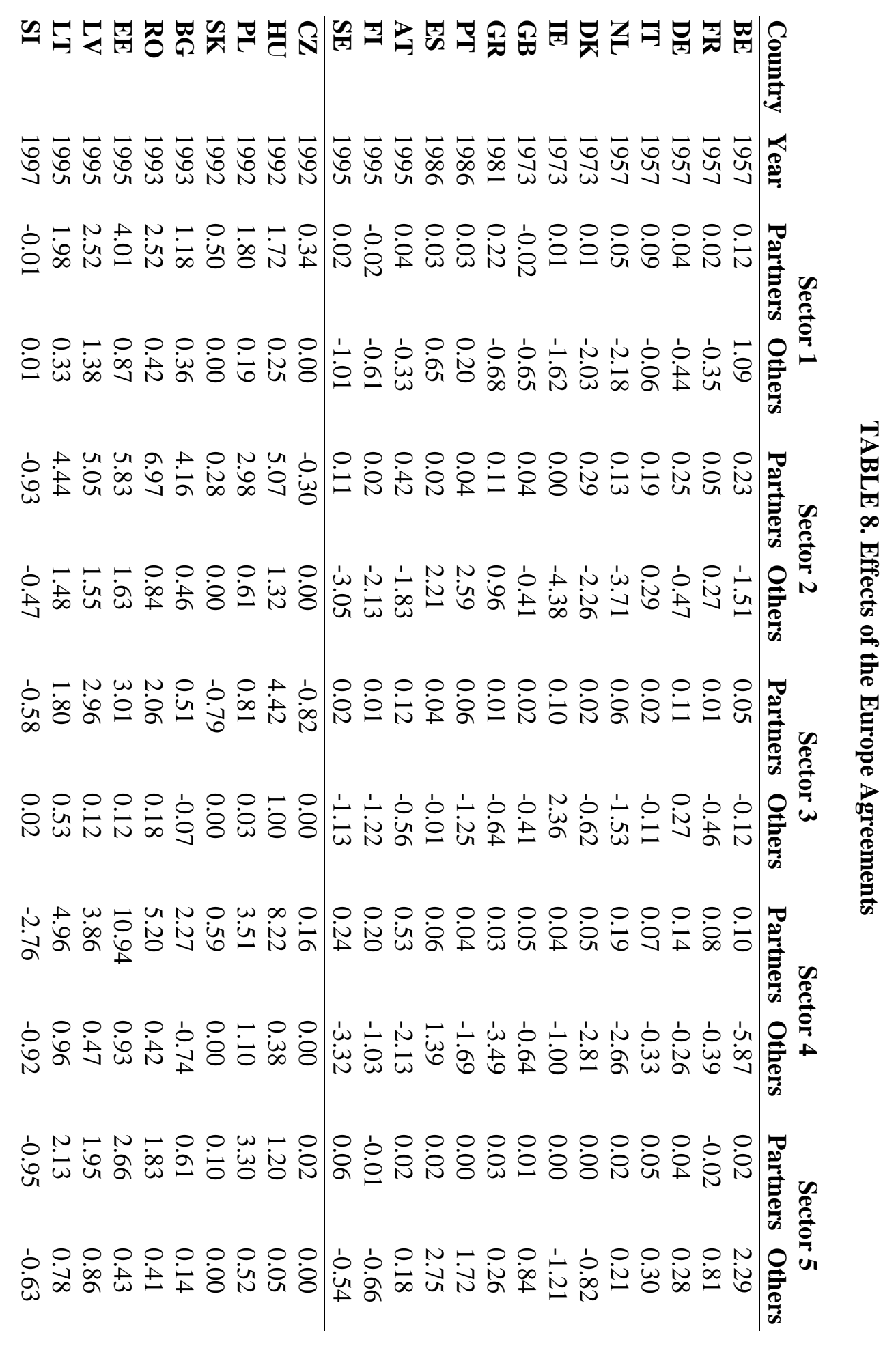




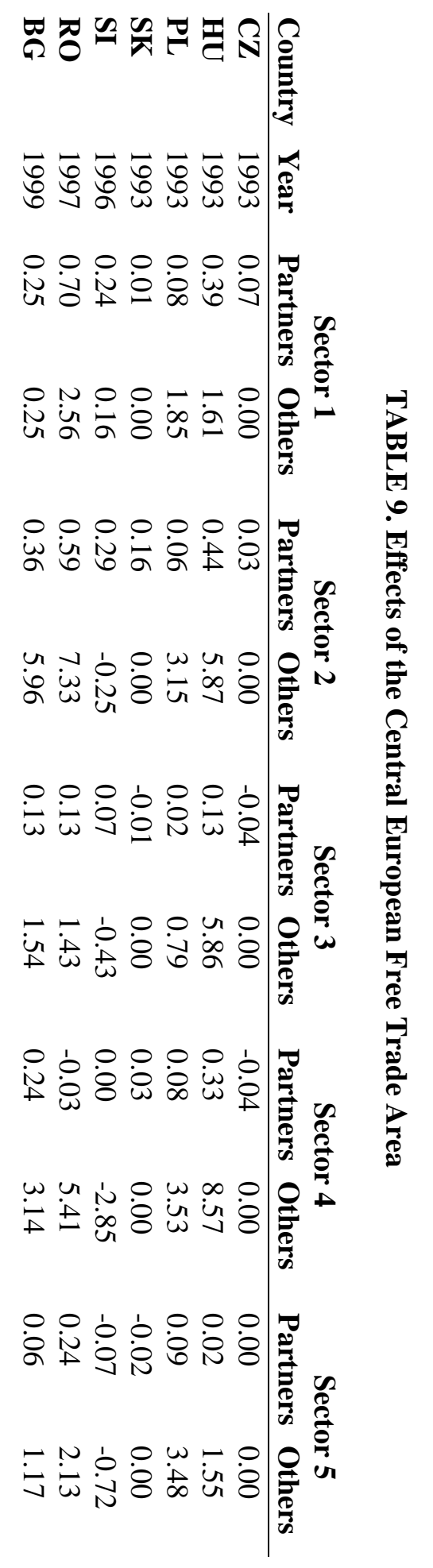




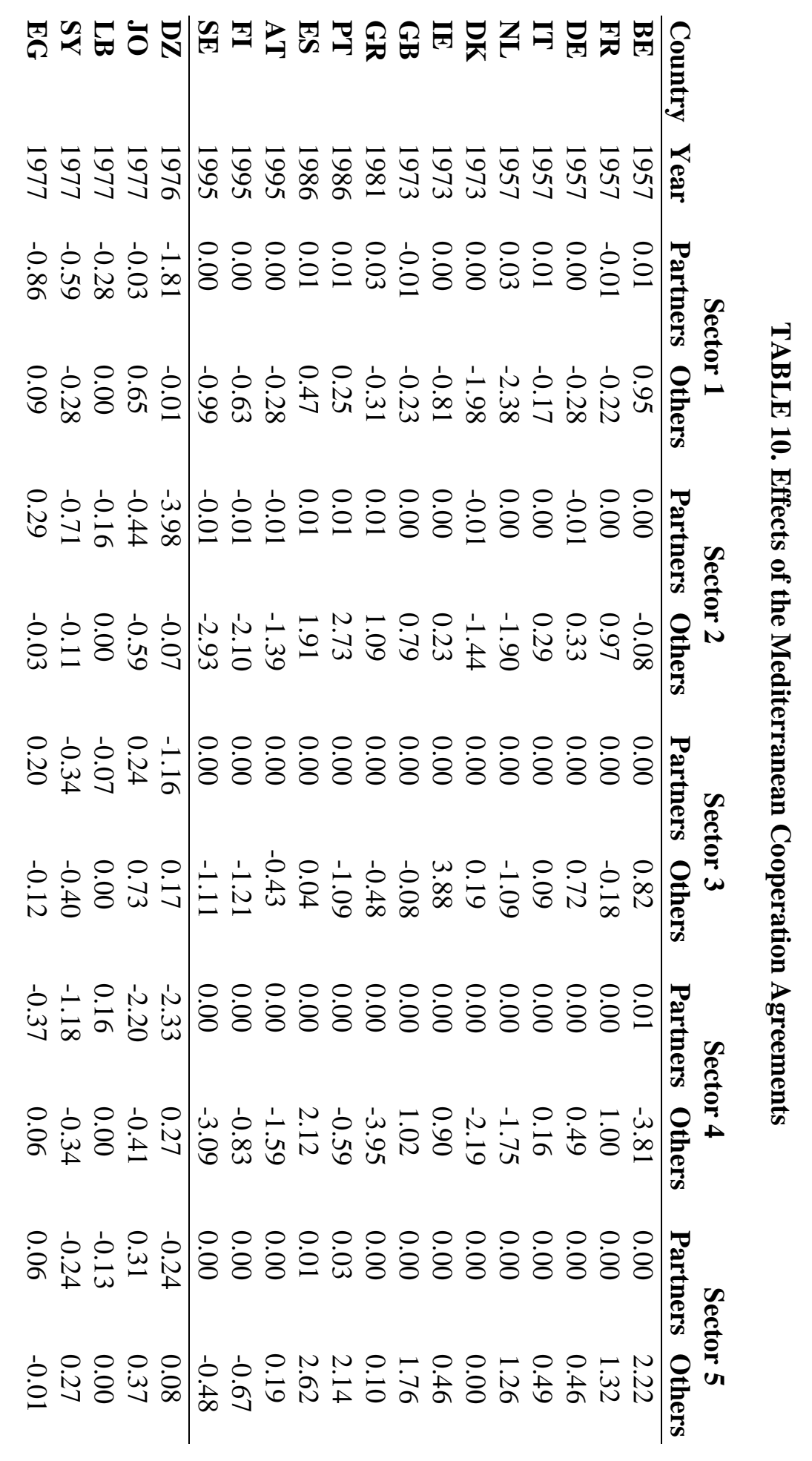




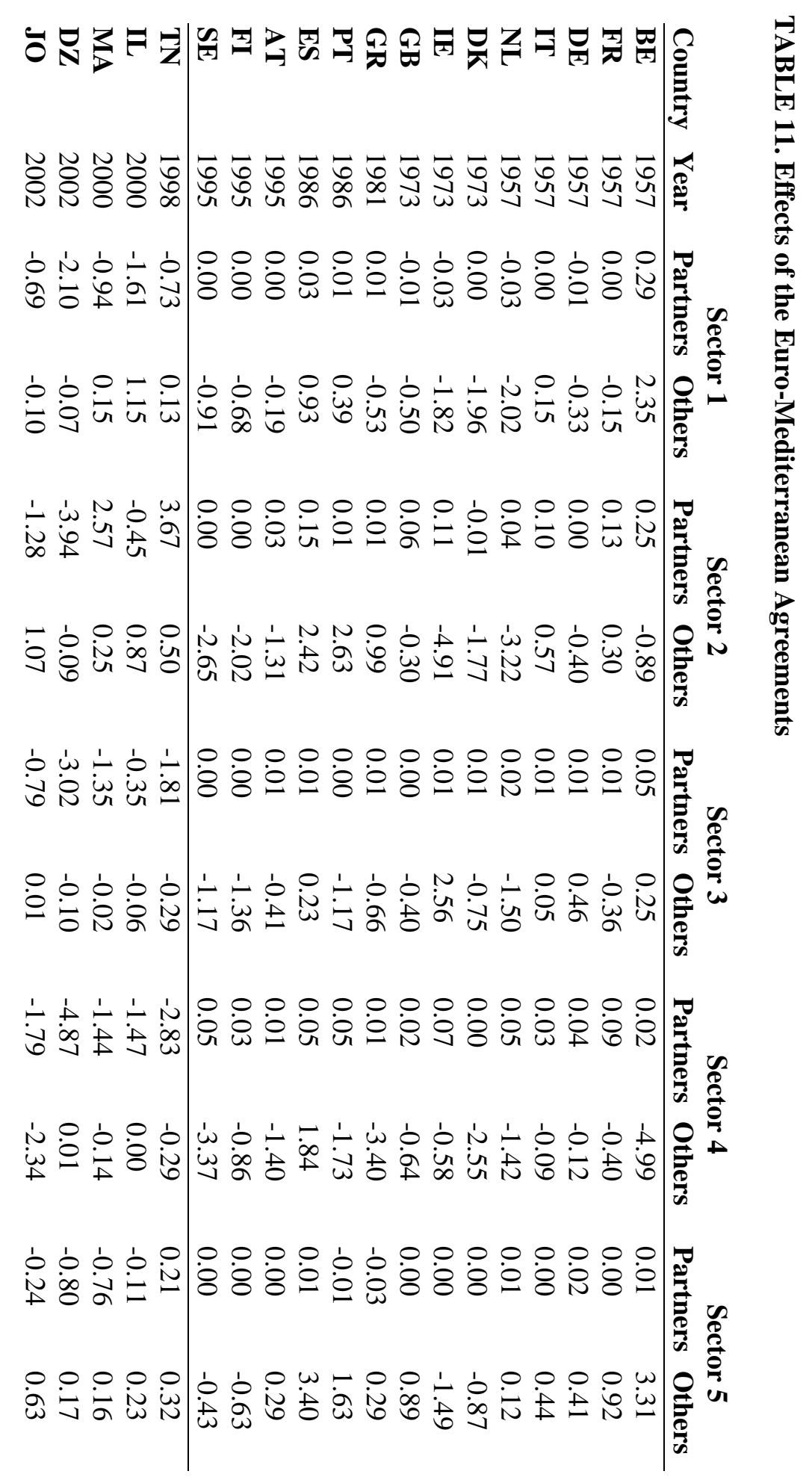


FIGURE 1. Trade diversion in resource- and labor-intensive sectors

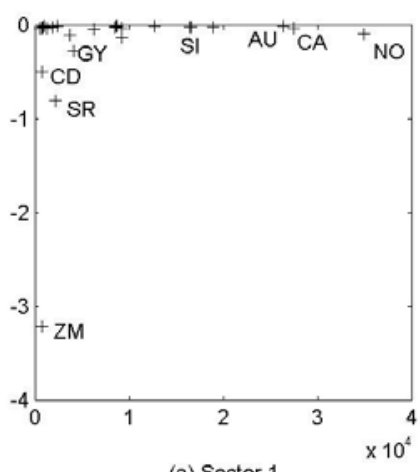

(a) Sector 1
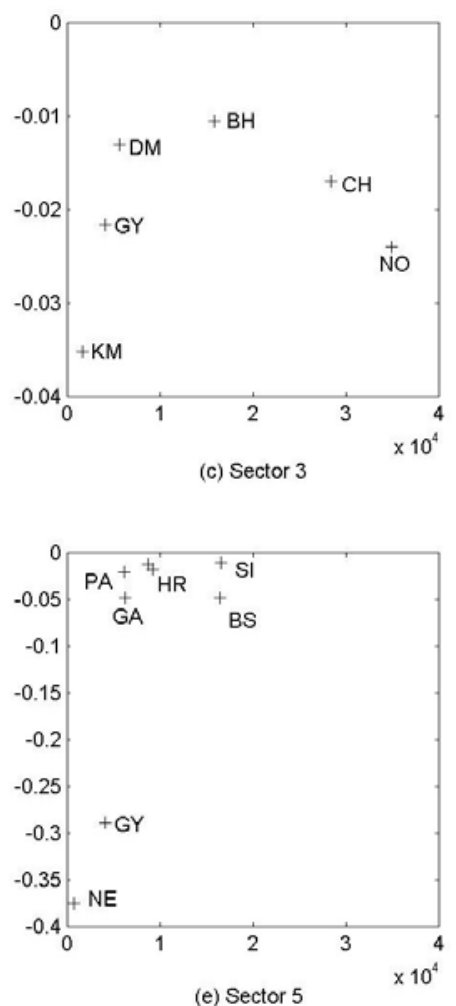

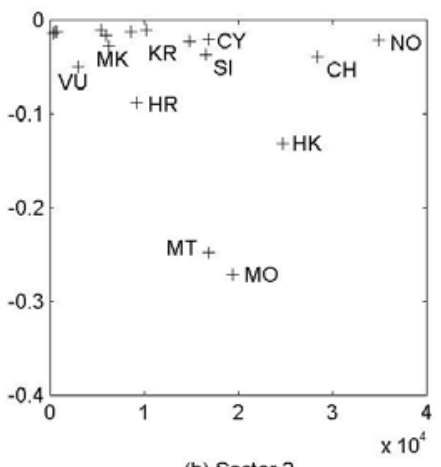

(b) Sector 2

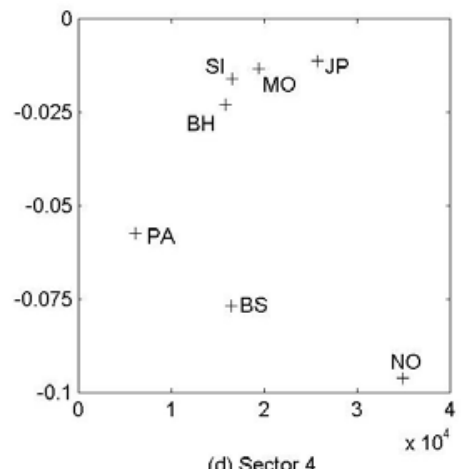

(d) Sector 4 
FIGURE 2. Overall trade diversion effects
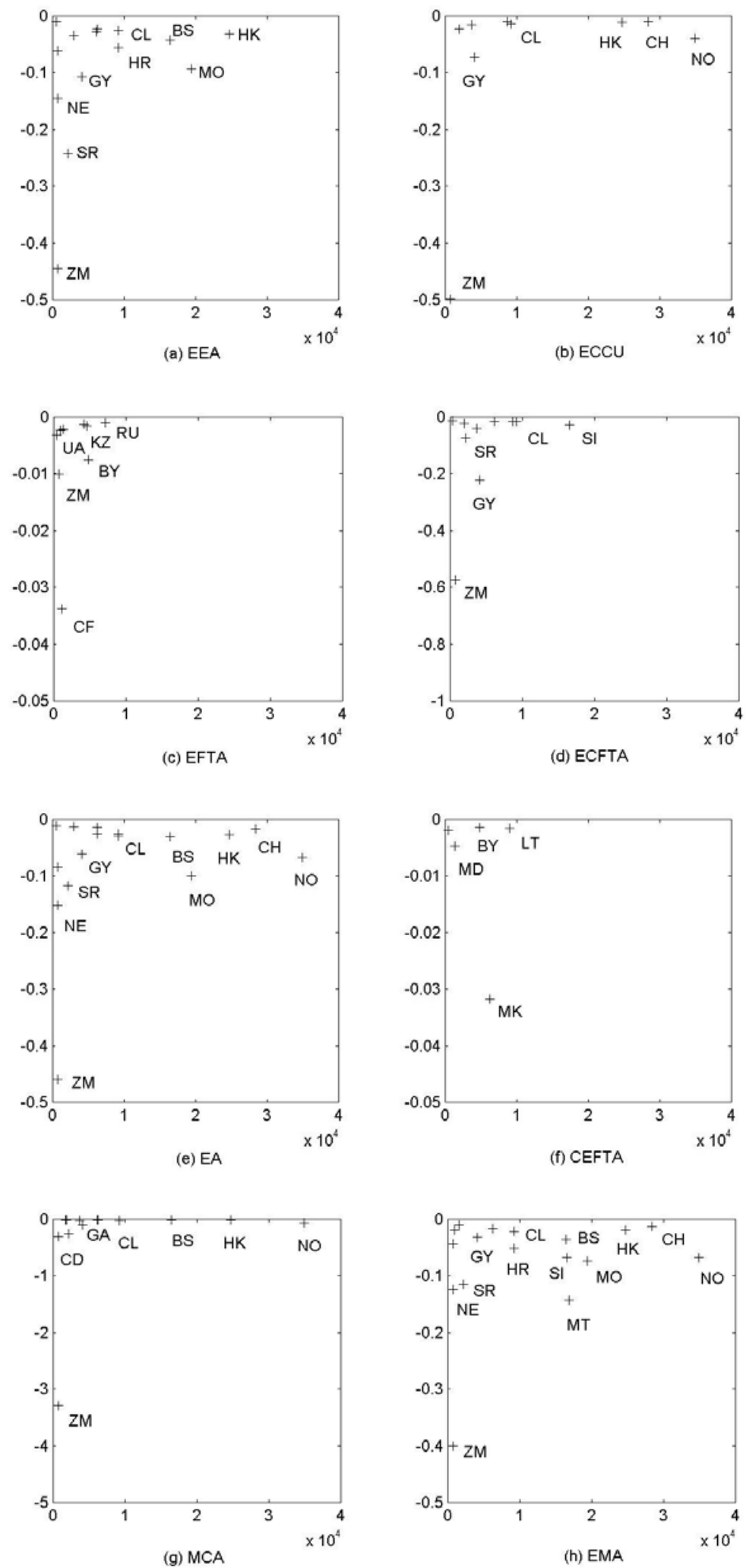


\section{Appendix A: SITC-2 codes of industries in each factor intensity sector}

1. Resource-intensive 51, 56, 61, 63, 64, 66, 67, 68

2. Labor-intensive 62, 65, 69, 79, 81, 82, 83, 84, 85, 86, 89

3. Human capital-intensive low technology 55,71

4. Human capital-and labor-intensive high technology 72, 73, 74, 75, 76, 77, 87, 88

5. Human and physical capital-intensive high technology 52, 53, 54, 57, 58, 59, 78

\section{Appendix B: Non-partner countries}

Angola(AO), Antigua and Barbuda(AI), Argentina(AR), Armenia(AM), Australia(AU), Azerbaijan(AZ), Bahamas(BS), Bahrain(BH), Bangladesh(BD), Barbados(BB), Belarus(BY), Belize(BZ), Benin(BJ), Bhutan(BT), Bolivia(BO), Bosnia Herzegovina(BA), Botswana(BW), Brazil(BR), Burkina Faso(BF), Burundi(BI), Cambodia(KH), Cameroon(CM), Canada(CA), Cape Verde(CV), Central African Rep.(CF), Chad(TD), Chile(CL), China(CN), Colombia(CO), Comoros(KM), Congo(CG), Costa Rica(CR), Cote d'Ivoire(CI), Dem. Rep. of Congo(CD), Djibouti(DJ), Dominica(DM), Dominican Rep.(DA), Ecuador(EC), El Salvador(SV), Equatorial Guinea(GQ), Eritrea(ER), Ethiopia(ET), Fiji(FJ), FS Micronesia(FM), Gabon(GA), Gambia(GM), Georgia(GE), Ghana(GH), Grenada(GD), Guatemala(GT), Guinea(GN), GuineaBissau(GY), Guyana(GY), Haiti(HT), Honduras(HN), Hong Kong(HK), India(IN), Indonesia(ID), Iran(IR), Jamaica(JM), Japan(JP), Kazakhstan(KZ), Kenya(KE), Korea(KR), Kuwait(KW), Kyrgyzstan(KG), Lao People’s Dem. Rep(LA)., Lesotho(LS), Libya(LY), Macao(MO), Madagascar(MG), Malawi(MW), Malaysia(MY), Maldives(MV), Mali(ML), Mauritania(MR), Mauritius(MU), Mexico(MX), Moldova(MD), Mongolia(MN), Mozambique(MZ), Namibia(NA), Nepal(NP), New Zealand(NZ), Nicaragua(NI), Niger(NE), Nigeria(N), Oman(OM), Pakistan(PK), Panama(PA), Papua New Guinea(PG), Paraguay(PY), Peru(PE), Philippines(PH), Russian Fed.(RU), Rwanda(RW), Saint Lucia(LC), Sao Tome and Principe(ST), Saudi Arabia(SA), Senegal(SN), Seychelles(SC), Sierra Leone(SL), Singapore(SG), South Africa(ZA), Solomon Islands(SB), Somalia(SO), Sri Lanka(LK), Sudan(SD), Suriname(SR), Swaziland(SZ), Tajikistan(TJ), Tanzania(TZ), Thailand(TH), Togo(TG), Tonga(TO), Trinidad and Tobago(TT), Uganda(UG), Ukraine(UA), United Arab Emirates(AE), Uruguay(UY), USA(US), Uzbekistan(UZ), Vanuatu(VU), Venezuela(VE), Vietnam(VN), Yemen(YE), Zambia(ZM), and Zimbabwe(ZW). 
${ }^{1}$ This variable was omitted in both Egger (2000) and Egger and Pfaffermayr (2003), arguing that its effects were captured by the time-invariant bilateral interaction fixed effect.

${ }^{2}$ Also, in labor-intensive sectors, exporter's GDP, and in human capital intensive sectors the similarity variable take the incorrect signs.

${ }^{3}$ The objective of the EMA is also to gradually liberalize trade in agriculture. However, all it does in concrete terms is to largely lock in the status quo. Negotiations to improve on existing agricultural concessions are to be initiated after 2000.

${ }^{4}$ The EU also has some preferential non-reciprocal trade agreements with their former colonies in Africa, the Caribbean and the Pacific under Lome/Cotonou Agreements. These countries' export performance in the EU market has been disappointing. Therefore, the EU proposed free trade agreements in place of the non-reciprocal access these countries enjoyed before just like the EMAs.

${ }^{5}$ Note that accession to the EU implies participation in the EEA, and the ECCU.

${ }^{6}$ Bulgaria and Romania are expected to join in 2007. The EU is expected to start accession negotiations with Turkey in 2005.

${ }^{7}$ These are the six original EU countries.

${ }^{8}$ Part of the reason could be that amount of trade in Sectors 1-2 is more than the trade in human capital-intensive sectors. 


\section{DAVIDSON INSTITUTE WORKING PAPER SERIES - Most Recent Papers}

The entire Working Paper Series may be downloaded free of charge at: www.wdi.bus.umich.edu

CURRENT AS OF 2/1/05

\begin{tabular}{|c|c|c|}
\hline Publication & Authors & Date \\
\hline $\begin{array}{l}\text { No. 746: Trade Creation and Diversion Effects of Europe’s Regional } \\
\text { Liberalization Agreements }\end{array}$ & Yener Kandogan & Feb. 2005 \\
\hline No. 745: Quality of Institutions, Credit Markets and Bankruptcy & Christa Hainz & Feb. 2005 \\
\hline $\begin{array}{l}\text { No. 744: How Transition Paths Differ: Enterprise Performance in Russia } \\
\text { and China }\end{array}$ & Sumon Bhaumik and Saul Estrin & Jan. 2005 \\
\hline $\begin{array}{l}\text { No. 743: Inflation Targeting, Between Rhetoric and Reality. The Case } \\
\text { of Transition Economies }\end{array}$ & Daniel Daianu and Laurian Lungu & Jan. 2005 \\
\hline $\begin{array}{l}\text { No. 742: How Does Law Affect Finance? An Empirical Examination of } \\
\text { Tunneling in an Emerging Market }\end{array}$ & $\begin{array}{l}\text { Vladimir Atanasov, Conrad S. } \\
\text { Ciccotello, \& Stanley B. Gyoshev }\end{array}$ & Jan. 2005 \\
\hline $\begin{array}{l}\text { No. 741: Do Insider Trading Laws Matter? Some Preliminary } \\
\text { Comparative Evidence }\end{array}$ & Laura Nyantung Beny & Jan. 2005 \\
\hline $\begin{array}{l}\text { No. 740: Autopsy on an Empire: Understanding Mortality in Russia and } \\
\text { the Former Soviet Union }\end{array}$ & $\begin{array}{l}\text { Elizabeth Brainerd and David M. } \\
\text { Cutler }\end{array}$ & Jan. 2005 \\
\hline $\begin{array}{l}\text { No. 739: Not Separate, Not Equal: Poverty and Inequality in Post- } \\
\text { Apartheid South Africa }\end{array}$ & $\begin{array}{l}\text { Johannes G. Hoogeveen and Berk } \\
\text { Özler }\end{array}$ & Jan. 2005 \\
\hline $\begin{array}{l}\text { No. 738: The Marketing Structure in Agribusiness during the Transition } \\
\text { in Bulgaria }\end{array}$ & $\begin{array}{l}\text { Steve Murray, Yordan Staykov, } \\
\text { and Valentin Katzerov }\end{array}$ & Jan. 2005 \\
\hline No. 737: Passive Creditors & $\begin{array}{l}\text { Koen Schoors and Konstantin } \\
\text { Sonin }\end{array}$ & Jan. 2005 \\
\hline $\begin{array}{l}\text { No. 736: From a currency board to the euro: Public attitudes toward } \\
\text { unilateral euroization in Bulgaria }\end{array}$ & Neven T. Valev & Jan. 2005 \\
\hline No. 735: Dictators and Their Viziers: Agency Problems in Dictatorships & $\begin{array}{l}\text { Georgy Egorov and Konstantin } \\
\text { Sonin }\end{array}$ & Jan. 2005 \\
\hline $\begin{array}{l}\text { No. 734: Foreign Investment, Corporate Ownership, and Development: } \\
\text { Are Firms in Emerging Markets Catching Up to the World Standard? }\end{array}$ & $\begin{array}{l}\text { Klara Sabirianova, Jan Svejnar, } \\
\text { and Katherine Terrell }\end{array}$ & Jan. 2005 \\
\hline $\begin{array}{l}\text { No. 733: Businessman Candidates: Special-Interest Politics in Weakly } \\
\text { Institutionalized Environments }\end{array}$ & $\begin{array}{l}\text { Scott Gehlbach and Konstantin } \\
\text { Sonin }\end{array}$ & Dec. 2004 \\
\hline $\begin{array}{l}\text { No. 732: Measuring the Institutional Change of the Monetary Regime } \\
\text { in a Political Economy Perspective }\end{array}$ & $\begin{array}{l}\text { Nikolay Nenovsky and Yorgos } \\
\text { Rizopoulos }\end{array}$ & Dec. 2004 \\
\hline $\begin{array}{l}\text { No. 731: Impact of Regulated Price Adjustments on Price Variability in } \\
\text { a Very Low Inflation Transition Economy: Case of Armenia }\end{array}$ & Aghassi Mkrtchyan & Nov. 2004 \\
\hline $\begin{array}{l}\text { No. 730: Reform, FDI and Economic Growth: Tale of the Tortoise and } \\
\text { the Hare }\end{array}$ & $\begin{array}{l}\text { Bruno Merlevede and Koen } \\
\text { Schoors }\end{array}$ & Nov. 2004 \\
\hline $\begin{array}{l}\text { No. 729: The Effects of Transition and Political Instability On Foreign } \\
\text { Direct Investment Inflows: Central Europe and the Balkans }\end{array}$ & $\begin{array}{l}\text { Josef C. Brada, Ali M. Kutan, } \\
\text { and Taner M. Yigit }\end{array}$ & Nov. 2004 \\
\hline $\begin{array}{l}\text { No. 728: Institutional Distance and International Business Strategies } \\
\text { in Emerging Economies }\end{array}$ & $\begin{array}{l}\text { Delia Ionascu, Klaus E. Meyer, } \\
\text { and Saul Erstin }\end{array}$ & Nov. 2004 \\
\hline No. 727: Explaining Patterns of Corruption in the Russian Regions & $\begin{array}{l}\text { Phyllis Dininio and Robert W. } \\
\text { Orttung }\end{array}$ & Nov. 2004 \\
\hline $\begin{array}{l}\text { No. 726: The Politics of Institutional Learning and Creation: Bank } \\
\text { Crises and Supervision in East Central Europe }\end{array}$ & Gerald A. McDermott & Nov. 2004 \\
\hline $\begin{array}{l}\text { No. 725: International Business and Development Economics: A } \\
\text { Winning Combination }\end{array}$ & Tamir Agmon & Nov. 2004 \\
\hline $\begin{array}{l}\text { No. 724: Importing High-Risk Capital and Revealing Hidden } \\
\text { Comparative Advantages }\end{array}$ & Tamir Agmon & Oct. 2004 \\
\hline $\begin{array}{l}\text { No. 723: Which entrepreneurs expect to expand their businesses? } \\
\text { Evidence from survey data in Lithuania }\end{array}$ & $\begin{array}{l}\text { Ruta Aidis and Tomasz } \\
\text { Mickiewicz }\end{array}$ & Oct. 2004 \\
\hline No. 722: Russia from Bust to Boom: Oil, Politics or the Ruble? & $\begin{array}{l}\text { Bruno Merlevede and Koen } \\
\text { Schoors }\end{array}$ & Oct. 2004 \\
\hline No. 721: Distance to the Efficiency Frontier and FDI Spillovers & $\begin{array}{l}\text { Klara Sabirianova Peter, Jan } \\
\text { Svejnar, and Katherine Terrell }\end{array}$ & Sept. 2004 \\
\hline $\begin{array}{l}\text { No. 720: An Analysis of Gender Wage Differentials in Russia from } \\
\text { 1996-2002 }\end{array}$ & Rita Hansberry & Sept. 2004 \\
\hline
\end{tabular}

